\title{
Evaluasi Sistem Informasi Akuntansi Persediaan Pada Dira Supermarket (Dira Shopping Center) Ambulu
}

\author{
Inayatul Qutsiyah ${ }^{1}{ }^{*}$, Moh. Halim², Rendy Mirwan $\mathrm{A}^{3}$ \\ 1,2,3 Fakultas Ekonomi Program Studi Akuntansi Universitas Muhammadiyah Jember
}

\section{A R T I C L E I N F O}

Article history:

Received 18 December 2018

Received in revised form

30 December 2018

Accepted 09 January 2019

Available online 19

February 2019

\section{Kata Kunci:}

Sistem Informasi,

Persediaan, Sistem

Informasi Akuntansi

Persediaan

Keywords:

Information System,

Inventory, Inventory

Accounting Information

System

\section{A B S T R A K}

Tujuan penelitian ini adalah untuk mengetahui kesesuaian sistem informasi akuntansi persediaan menurut konsep dan teori pada Dira Supermarket Ambulu. Jenis data yang digunakan adalah data kualitatif dengan sumber data primer dan sekunder. Penelitian ini dilakukan dengan teknik analisis data kualitatif melalui wawancara dan dokumentasi. Hasil penelitian menunjukkan bahwa sistem informasi akuntansi yang diterapkan oleh Dira Supermarket Ambulu terdapat beberapa prosedur yang tidak sesuai dengan konsep dan teori.

\section{A B S T R A C T}

The purpose of this study was to determine the suitability of inventory accounting information systems according to the concepts and theories of the Ambulu Supermarket Dira. The type of data used is qualitative data with primary and secondary data sources. This research was conducted with qualitative data analysis techniques through interviews and documentation. The results showed that the accounting information system implemented by Dira Supermarket Ambulu contained several procedures that were not in accordance with concepts and theories.

\footnotetext{
* Corresponding author.

E-mail addresses: anggrainiarum27@gmail.com (Inayatul Qutsiyah)
} 


\section{Pendahuluan}

Kegiatan penyimpanan barang sebagai bentuk persediaan sangat erat kaitannya dengan bidang penjualan ibarat mata rantai yang tidak bisa terlepas satu sama lain. Persediaan barang sebagai hal utama dalam modal kerja merupakan aset yang selalu berputar secara kotinyu mengalami perubahan.

Dira Supermarket Ambulu merupakan perusahaan dagang yang bergerak di bidang retail dan swalayan. Pada pengelolaan dan pengendalian barang dagang pada Dira Supermarket Ambulu sering terjadi selisih stok persediaan pada gudang dengan catatan persediaan yang ada. Hal tersebut mengindikasikan bahwa sistem informasi akuntansi persediaan barang dagang kurang berjalan efektif sehingga mengakibatkan adanya perbedaan antara jumlah fisik persediaan dengan catatan yang tersedia ketika dilakukan penghitugan fisik.

Tabel 1. Selisih persediaan barang pada Dira Supermarket Ambulu

\begin{tabular}{|c|c|c|c|c|c|c|c|}
\hline \multirow[t]{2}{*}{ KODE } & \multicolumn{2}{|c|}{$\begin{array}{l}\text { DALAM SISTEM } \\
\text { PENCATATAN (NILAI } \\
\text { BUKU) } \\
\text { PERSEDIAAN AKHIR }\end{array}$} & \multicolumn{2}{|c|}{$\begin{array}{l}\text { TERSEDIA DIGUDANG } \\
\text { (FISIK) } \\
\text { PERSEDIAAN } \\
\text { GUDANG }\end{array}$} & \multicolumn{2}{|c|}{$\begin{array}{ll}\text { HASIL } & \text { DARI } \\
\text { KEGIATAN } & \text { STOK } \\
\text { OPNAME } & \\
\text { SELISIH } & \\
\text { KURANG/LEBIH }\end{array}$} & \multirow[t]{2}{*}{ KET } \\
\hline & ML & NILAI & JML & NILAI & ML & NILAI & \\
\hline 10301046 & 50 & Rp 740.000 & 48 & Rp 710.400 & -2 & $\mathrm{Rp}(29.600)$ & RUSAK \\
\hline 10300063 & 12 & Rp 285.120 & 10 & Rp 237.600 & -2 & $\operatorname{Rp}(47.520)$ & RUSAK \\
\hline 11000004 & 40 & Rp 3.076.000 & 39 & Rp 2.999.100 & -1 & $\operatorname{Rp}(76.900)$ & HILANG \\
\hline 11000013 & 12 & Rp 654.000 & 11 & Rp 599.500 & -1 & $\mathrm{Rp}(54.500)$ & HILANG \\
\hline 10300066 & 200 & Rp 3.740 .000 & 199 & Rp 3.721.300 & -1 & $\operatorname{Rp}(37.400)$ & RUSAK \\
\hline 10300067 & 200 & Rp 3.740 .000 & 198 & Rp 3.702.600 & -2 & $\mathrm{Rp}(37.400)$ & SALAH CATAT \\
\hline 9011409 & 150 & Rp 2.760.000 & 150 & Rp 2.760.000 & 0 & - & - \\
\hline 11000003 & 50 & $\mathrm{Rp} 4.180 .000$ & 45 & Rp 3.897.000 & -5 & $\mathrm{Rp}(433.000)$ & SALAH CATAT \\
\hline 11000152 & 12 & Rp 603.600 & 10 & Rp 503.000 & -2 & $\mathrm{Rp}(100.600)$ & RUSAK \\
\hline $\begin{array}{l}10200593 \\
\text { Total }\end{array}$ & 10 & $\begin{array}{l}\text { Rp } 1.147 .000 \\
\text { Rp 20.925.720 }\end{array}$ & 7 & $\begin{array}{l}\text { Rp } 802.900 \\
\text { Rp 19.933.400 }\end{array}$ & -3 & $\begin{array}{l}R p(344.100) \\
\mathbf{R p} \\
(\mathbf{1 . 1 2 3 . 6 2 0 )}\end{array}$ & RUSAK \\
\hline
\end{tabular}

Data diatas menunjukkan selisih persediaan barang yang terjadi pada Dira Supermarket Ambulu. Berdasarkan konsep dan teori yang dikemukakan oleh Diana dan Setiawati (2017) selisih persediaan barang secara fisik dengan persediaan barang berdasarkan catatan akan berdampak dan berpengaruh terhadap penentuan beban pokok penjualan barang.

Iman Haidar (2017) melakukan penelitian mengenai Analisis Sistem Informasi Akuntansi Persediaan Bahan Baku Tembakau pada pabrik PT. Ongkowidjojo Gadang Malang yang bertujuan untuk mengetahui penerapan dan mengevaluasi sistem informasi akuntansi atas pembelian, permintaan, pengeluaran, pengembalian bahan baku tembakau di PT. Ongkowidjojo. Penelitian ini menggunakan metode analisis kualitatif deskriptif dengan melakukan penelitian langsung ke lapangan untuk memperoleh data dengan cara observasi dan wawancara yang kemudian dikombinasikan dengan literature yang berhubungan dengan penelitian. Hasil penelitian ini menunjukkan bahwa sistem pembelian, permintaan, pengeluaran dan pengembalian bahan baku dari gudang serta sistem perhitungan fisik susdah berjalan sesuai prosedurnya. Kesalahan yang terjadi adalah pada perhitungan fisik bahan baku berupa regrin yang ditimbulkan karena adanya prosedur pembelian persediaan bahan baku yang dijalankan oleh perusahaan.

Berdasarkan fenomena diatas penulis tertarik untuk mengetahui dan memahami bagaimana sistem informasi akuntansi persediaan barang yang diterapkan dalam perusahaan sehingga dapat bermanfaat bagi masyarakat. Untuk itu penulis menulis dengan judul "Evaluasi Sistem Informasi Akuntansi Persediaan pada Dira Supermarket Ambulu". 


\section{Metode}

Metode dan Jenis Penelitian

Menurut Bugin (2011) penelitian menggunakan teknik deskriptif kualitatif bertujuan untuk menggambarkan, meringkas berbagai kondisi, berbagai situasi, atau berbagai fenomena realitas social yang ada di masyarakat yang menjadi objek penelitian, dan berupaya menarik realita itu ke permukaan sebagai suatu ciri, karakter, sifat, model, tanda, atau gambaran tentang kondisi, situasi, ataupun fenomena tertentu.

Metode penelitian yang digunakan adalah metode deskriptif kualitatif. Penelitian diawali dengan menemui Manager atau penanggungjawab untuk meminta izin terkait dengan pelaksanaan penelitian, selanjutnya melaksanakan penelitian dengan melakukan wawancara dan observasi yang berkaitan dengan persediaan barang pada Dira Supermarket Ambulu.

\section{Jenis dan Sumber Data}

Sumber data penelitian adalah faktor utama yang menjadi pertimbangan dalam penentuan metode pengumpulan data. Penelitian ini menggunakan metode kualitatif berupa analisis Sistem Informasi Akuntansi Persediaan barang dagang dengan mengambil studi kasus pada Dira Supermarket Ambulu. Dalam penelitian ini, jenis data yang digunakan adalah jenis data primer dan sekunder.

Teknik Pengumpulan Data

Wawancara

Wawancara yang dilakukan guna mendapatkan informasi mengenai persediaan barang pada Dira Supermarket Ambulu. Wawancara pertama dilakukan kepada General Manager dengan alasan, beliau bertanggungjawab penuh dan secara keseluruhan terhadap prosedur yang berlaku di perusahaan. Wawancara kedua kepada Admin Purchase Order dengan alasan karena memiliki tanggungjawab terhadap kebutuhan perusahaan untuk menyediaan persediaan barang. Wawancara ketiga kepada admin Penerimaan Barang yang bertanggungjawab terhadap kondisi dan kesesuaian barang yang dipesan dan diterima oleh perusahaan. Wawancara selanjutnya kepada koordinator area yang bertanggungjawab terhadap kondisi dan keadaan barang persediaan selama berada di gudang.

Dokumentasi

Dokumentasi yang dilakukan dengan mengumpulkan data-data yang tersedia di perusahaan yang berkaitan dengan prosedur persediaan barang yang meliputi Faktur Pembelian, Daftar Purchase Order (PO), Daftar Stock Barang, dan Laporan Transfer Barang. Dokumen-dokumen tersebut sangat bermanfaat dalam menganalisi dan pemecahan masalah yang terjadi pada perusahaan tersebut.

Metode Analisis Data

Metode analisis data yang digunakan adalah analisis kualitatif deskriptif, dengan menganalisis terhadap data yang diperoleh saat penelitian, guna memperoleh gambaran umum perusahaan secara menyeluruh yang meliputi Gambaran umum perusahaan, Struktur organanisasi pada Dira Supermarket Ambulu, Sistem dan prosedur pemesanan dan persediaan barang yang diterapkan pada Dira Supermarket Ambulu, Dokumen-dokumen yang digunakan, termasuk yang terkait dengan Sistem Informasi Akuntansi Persediaan pada Dira Supermarket Ambulu, Membandingkan sistem dan prosedur siklus persediaan yang diterapkan pada Dira Supermarket Ambulu dengan Konsep dan Teori, dan menarik kesimpulan, merupakan langkah terakhir dalam analisis data, sistem dan prosedur pembelian dan persediaan pada Dira Supermarket Ambulu.

\section{Hasil dan pembahasan}

\section{Evaluasi Sistem Informasi Akuntansi Persediaan pada Dira Supermarket Ambulu}

Pada prosedur pemesanan persediaan sebelum barang menipis, koordinator area (gudang) membuat daftar atau laporan persediaan yang terdapat pada gudang selanjutnya diserahkan kepada admin atau bagian PO (Purchase Order). Ini dilakukan untuk mengetahui barang apa saja yang diperlukan berdasarkan persetujuan General Manager.

Untuk prosedur retur dan potongan harga, retur penjualan terjadi apabila barang yang dikirim ada sedikit cacat atau barang tidak sesuai dengan pesanan. Setelah barang retur datang, bagian penerimaan akan membuat laporan pengiriman barang, selajutnya bagian gudang mencatat tambahan kuantitas barang yang akan masuk dalam kartu gudang, dan admin keuangan mencatat tambahan harga pokok yang diterima dari suplier. Dokumen yang digunakan dalam prosedur retur dan potongan pembelian adalah laporan penerimaan barang atau pesanan.

Dalam prosedur penerimaan dan penyimpanan barang, Koordinator area membuat daftar atau laporan barang sebelum stok habis untuk diserahkan ke admin $P O$ untuk melakukan pemesanan barang 
berdasar dengan persetujuan general manager. Koordinator area beserta admin $P O$ melakukan pengecekan atas barang yang diterima. Dan bagian penerimaan barang membuat surat tanda terima berdasarkan fisik barang yang diterima digudang. Jika tidak sesuai atau ada kerusakan terhadap barang, maka bagian penerimaan barang dan koordinator gudang akan segera membuat berita acara atas kondisi barang yang diterima kemudian menyampaikan kepada admin $P O$.

Prosedur pengeluaran barang dari gudang atau transfer barang, Koordinator area mengeluarkan barang dengan metode FIFO, barang yang pertama masuk akan dikeluarkan pertama kali. Koordinator gudang mencatat setiap pengeluaran barang dan membuat form pengeluaran atau transfer barang kemudian ditandatangani oleh kooordinator gudang. Barang yang keluar atau ditransfer dari gudang akan disertai dengan form pengeluaran barang berdasarkan kuantitas yang dikeluarkan.

Prosedur pencatatan persediaan pada Dira Supermarket Ambulu pencacatan pada catatan persediaan yang telah terkomputerisasi dan dengan metode perhitungan fisik, karena dengan perhitungan fisik persediaan (stock opname) digunakan untuk mengetahui kuantitas barang yang masih ada, selanjutnya diperhitungkan harga pokoknya.

Pada prosedur perhitungan Fisik Persediaan dilakukan tiga sampai enam bulan sekali oleh petugas yang terkait dan bagian gudang. Tujuan dilakukannya stock opname ini adalah untuk mengetahui keakuratan catatan pengendalian stok persediaan. Dan dalam pengelolaan persedian, metode yang diterapkan oleh Dira Supermarket Ambulu adalah metode FIFO (barang yang masuk pertama keluar pertama), yaitu metode harga pokok persediaan berdasarkan dengan urutan masuknya barang. Untuk mengevaluasi persediaan perusahaan melakukan kegiatan stock opname dengan menghitung persediaan fisik digudang untuk kemudian dijual. Melalui stock opname akan diketahui keakuratan pembukuan stok persediaan.

\section{Gambar 1 \\ Prosedur Pemesanan Barang}

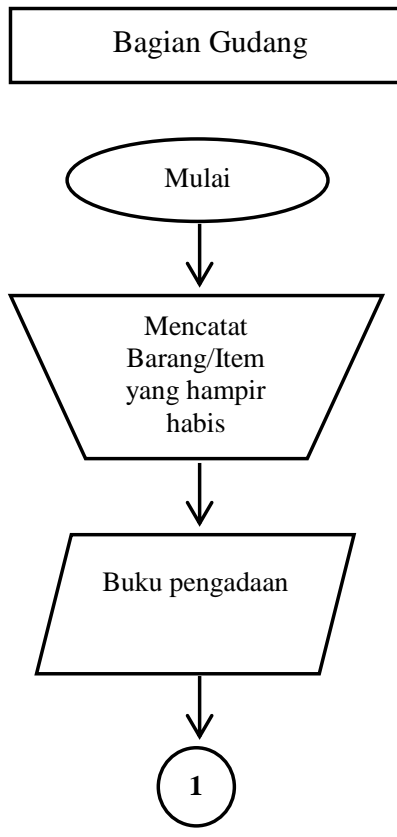

Bagian Pemesanan Barang/PO

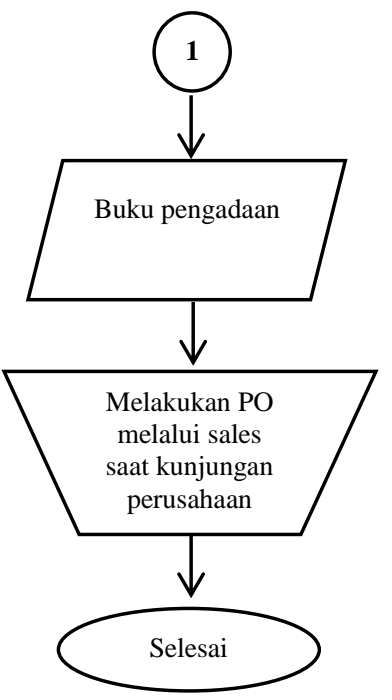

Sumber : Data Olahan Penulis 


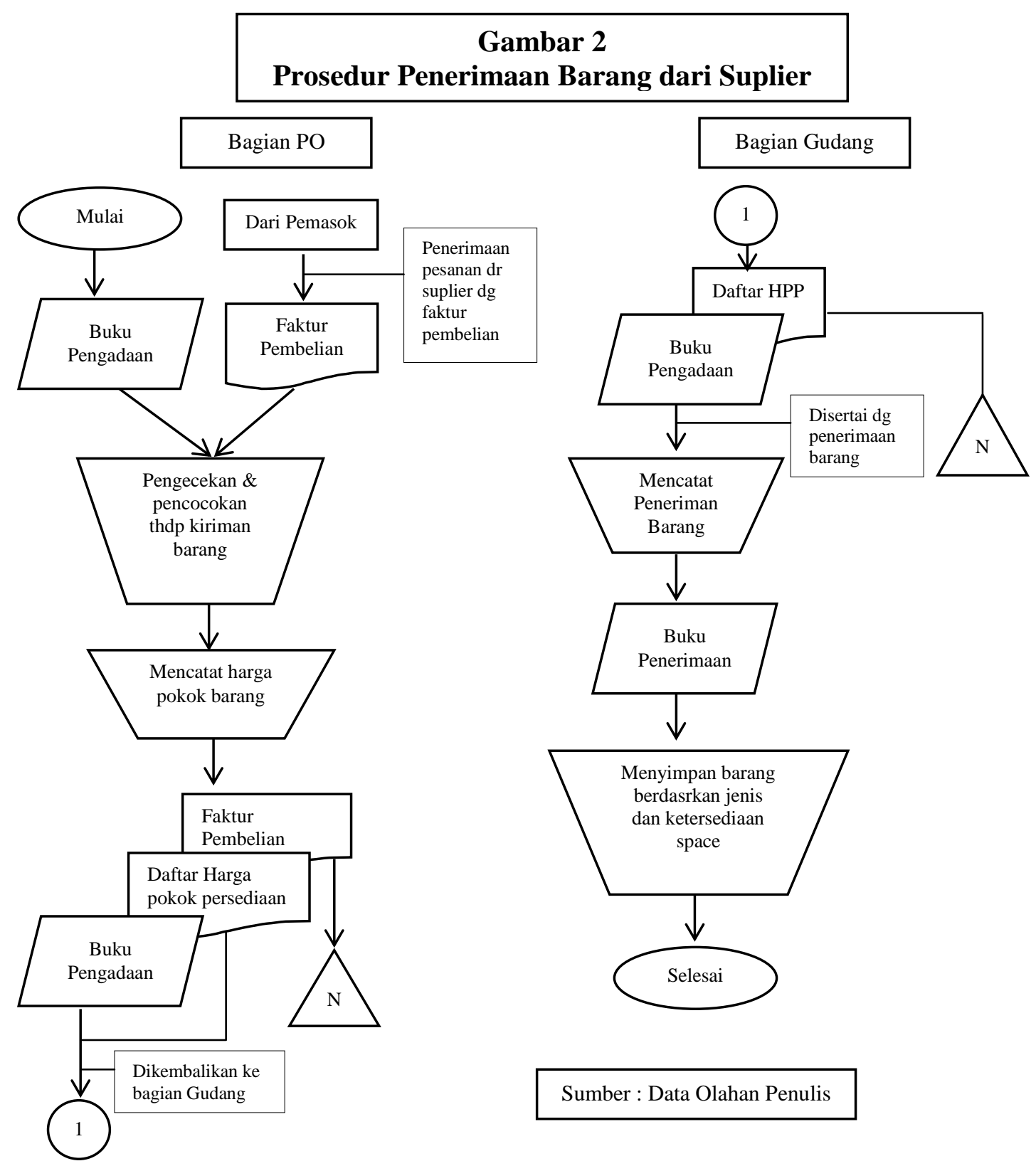




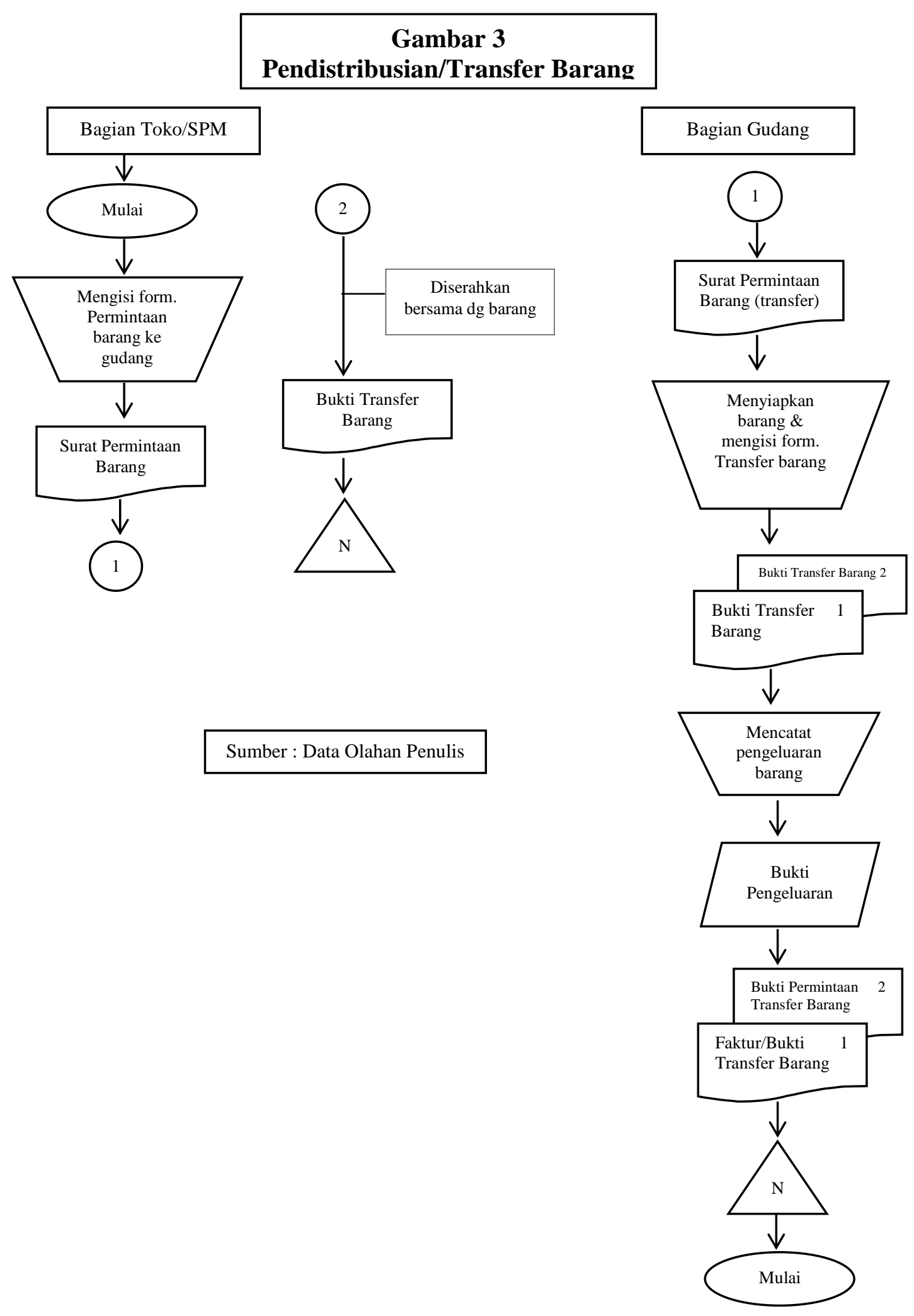




\section{Gambar 2
Prosedur Penghitungan Fisik Persediaan}
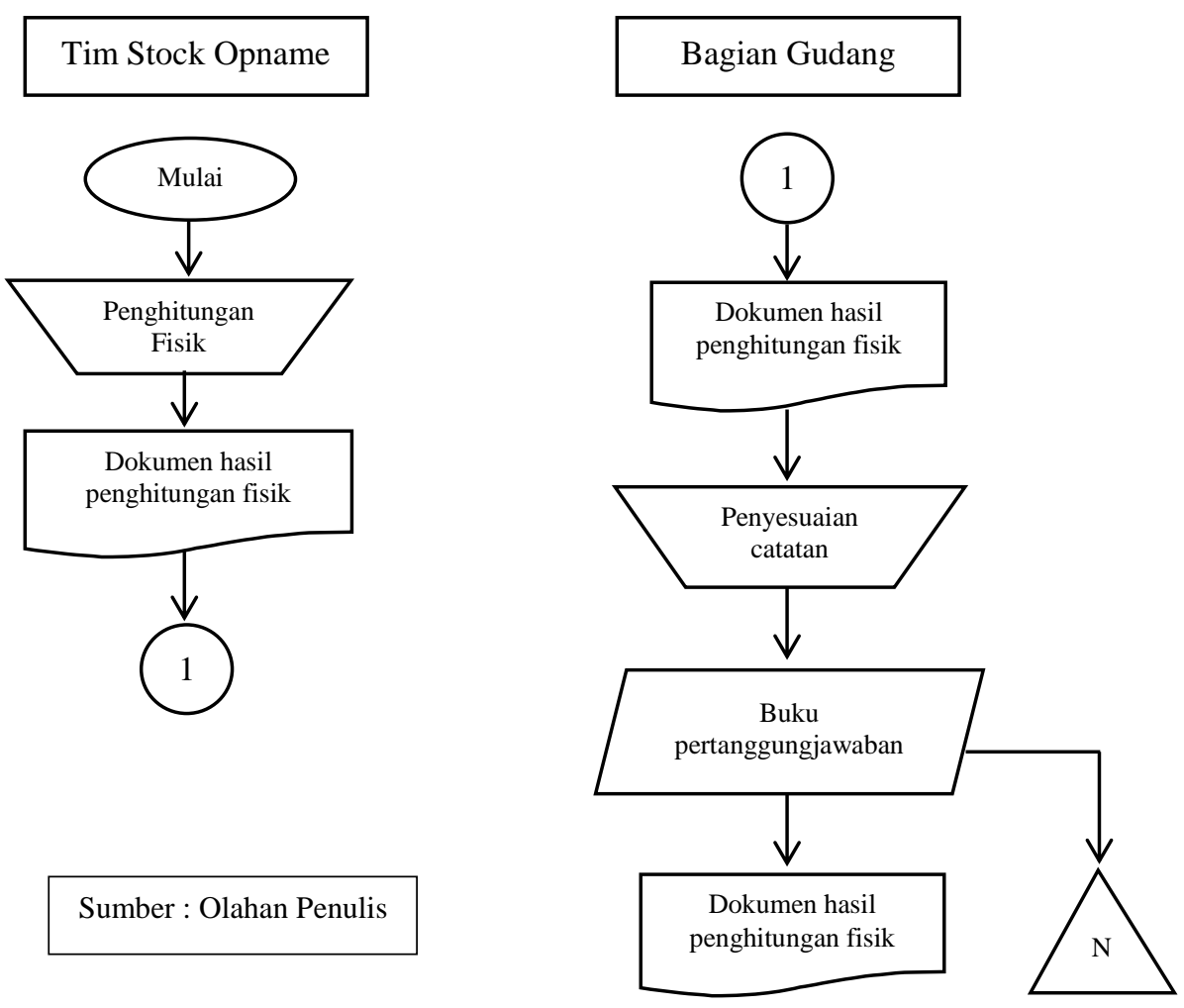

\section{Perlakuan Selisih Persediaan pada Dira Supermarket Ambulu}

\section{Barang Rusak}

Ketika terjadi selisih persediaan barang di gudang dengan catatan yang ada maka pihak Dira akan mengembalikan/meretur barang yang rusak tersebut kepada supplier. Ketika pihak perusahaan memberitahukan atau melaporkan adanya kerusakan barang, maka pihak supplier mendatangi perusahaan guna mengambil catatan atau laporan barang yang akan di kembalikan/diretur oleh perusahaan pada supplier. Kemudian, supplier akan memberi pilihan kepada manajemen Dira, barang yang akan di retur tersebuat akan diganti dengan barang yang sama, atau dengan mengembalikan sejumlah biaya pembelian yang sesuai dengan harga barang yang di retur.

Barang yang diretur kepada supplier, tidak hanya barang cacat/rusak tetapi juga barang yang hampir mendekati expired. Dengan ketentuan yang sama seperti halnya prosedur retur barang rusak, pihak Dira akan memberi laporan terlebih dahulu kepada supplier. Hanya saja, pengembalian atau retur barang yang mendekati masa expired ada ketentuan khusus dalam prosedur returnya, yaitu dengan memberi laporan maksimal tiga bulan sebelum masa expired barang tersebut.

\section{Barang Hilang}

Terjadinya selisih stok persediaan yang ada pada gudang dan catatan persediaan pada Dira Supermarket Ambulu ketika terdapat barang hilang, pihak Manajemen membuat ketentuan kepada seluruh karyawan yang terlibat dengan mengganti barang yang hilang sesuai atau sejumlah barang yang hilang tersebut.

Umumnya, adanya barang hilang dapat diketahui setelah selesai melakukan stock opname. Pelaksanaan stock opname sendiri dilakukan dua kali pada satu periode mengingat banyaknya barang dan padatnya transaksi yang terjadi pada Dira Supermarket ambulu setiap harinya.

3. Salah Catat

Untuk kesalahan pencatatan persediaan stok barang gudang, dapat langsung diperbaiki ketika ada laporan atau tanda yang diberikan oleh komputer akan kesalahan pencatatan tersebut dengan cara menghapus kesalahan transaksi kemudian mengganti dengan jurnal yang benar, saat transaksi yang memiliki kesalahan pencatatan, posting pada akun secara otomatis juga dihapus sehingga akan menghilangkan pengaruh dari kesalahan pencatatan terhadap catatan pesediaan tersebut. 
Perlakuan selisih Persediaan barang berdasarkan Konsep dan Teori

Kesalahan pencatatan pada persediaan akan berakibat terhadap penentuan harga pokok barang yang dijual yang juga akan berdampak terhadap kesalahan pada laporan keuangan. Jika persediaan barang pada akhir periode dilaporkan lebih atau terlalu rendah, maka beban pokok penjualan akan menjadi terlampau tinggi yang pada akhirnya akan menyebabkan laba bersih yang diperoleh perusahaan akan menjadi terlalu rendah. Pada laporan posisi keuangan, apabila laporan atas persediaan terlampau rendah, maka modal kerja (aset lancar dikurangi liabilitas lancar) dan rasio lancar (aset lancar dibagi liabilitas lancar) menjadi terlalu rendah pula.

Apabila persediaan awal dan pembelian dalam pencatatan secara benar dan sesuai. Namun, beberapa barang atau item persediaan tidak terdapat pada persediaan akhir atau pada pembelian terdapat persediaan yang tidak dicatat, maka persediaan dan utang dagang dalam laporan posisi keuangan menjadi terlalu rendah dan rasio lancar akan menjadi terlalu tinggi. Pembelian sebagai faktor penambah dan persediaan akhir sebagai faktor pengurang pada penghitngan beban pokok penjualan menyebabkan kesalahan tersebut saling meniadakan. Jika pembelian dicatat terlalu tinggi, maka dampaknya terhadap laporan posisi keuangan merupakan kebalikan dari yang telah dijelaskan diatas.

Prosedur pada akhir periode untuk persediaan barang pada saat Pencatatan persediaan yang menggunakan metode atau sistem periodik, akun pembelian akan digunakan dan akun persediaan tidak akan berubah selama periode tersebut. Akun persediaan menyajikan suatu jumlah awal selama periode tertentu. Pada akhir periode, akun persediaan harus disesuaikan dengan menutup akun jumlah persediaan awal dan mencatat jumlah persediaan akhir. Persediaan akhir ditentukan oleh penghitungan fisik item atau barang yang dimiliki dan dinilai berdasarkan harga perolehan atau nilai yang paling rendah antara harga pokok dan harga pasar. Dalam sistem persediaan periodik, harga pokok barang yang dijual, kemudian ditentukan dengan menambahkan persediaan awal bersama-sama dengan pembelian bersih dan dikurang dengan persediaan akhir.

Penghitungan harga pokok yang dijual dalam sistem akuntansi persediaan periodik mempunyai karakteristik baik berupa ayat jurnal penyesuaian maupun ayat jurnal penutup. Terdapat beberapa cara untuk menyajikan jurnal untuk memutakhirkan persediaan, mencatat harga pokok barang yang dijual, dan menutup akun nominal lainnya.

Metode pertama terdiri atas penyajiian seperangkat ayat jurnal untuk menyesuaikan persediaan, untuk menutup akun yang terkait dengan pembelian, dan penentuan harga pokok barang yang dijual dalam sistem persediaan periodik. Dua ayat jurnal penyesuaian pertama atas akun persediaan secara umum dipandang sebagai jurnal penyesuaian. Sementara jurnal ketiga untuk mengalihkan pembelian bersih ke dalam harga pokok barang yang dijual dipandang sebagai jurnal penutup. Harga pokok barang yang dijual yang tetap ditutup.alternatifnya, metode kedua guna mengalihkan berbagai akun persediaan dalam sistem persediaan periodik ke dalam akun harga pokok barang yang dijual untuk menyiapkan suatu ayat jurnal penutup.

Berdasarkan penjelasan diatas, dapat diketahui bahwa perlakuan terhdap selisih persediaan yang diterapkan pada Dira Supermarket ambulu berbeda dengan konsep dan teori. Pada Dira, perlakuan terhadap persediaan barang atau item yang hilang akan menjadi tanggung jawab karyawan dalam pengelolaan barang persediaan, karena pada proses awal penerimaan barang dari supplier, jumlah dan kondisi barang sudah melalui tahap pengecekan oleh bagian yang terkait, apabila pada awal penerimaan barang tersebut tidak sesuai dengan pemesanan dan kondisi seharusnya, maka pihak perusahaan akan mengembalikan barang tersebut dengan ketentuan-ketentuan yang telah disepakati kedua pihak. Berbeda dengan yang diterapkan oleh Manajemen Dira, dalam konsep dan teori untuk perlakuan terhadap selisih persediaan barang atau item yang baik itu kondisi rusak, salah catat maupun hilang, ada cara tersendiri yaitu dengan membuat akumulasi terhadap persediaan yang ada, selain itu pada teori juga di jelaskan bahwa sebaiknya perusahaan mempunyai anggaran tersendiri terhadap pengelolaan persediaan hingga persediaan atau barang tersebut keluar dari penyimpanan dan terjual kepada konsumen

\section{Simpulan dan saran}

Berdasarkan hasil evaluasi yang telah dilakukan, disimpulkan bahwa sistem akuntansi persediaan yang diterapkan oleh Dira Supermarket Ambulu untuk sistem pembelian dan pemesanan barang, sistem permintaan dan pengeluaran barang gudang pada Dira Supermarket Ambulu sudah cukup baik, hal ini dapat dilihat dari fungsi yang terkait, dokumen yang digunakan, catatan akuntansi yang digunakan dan jaringan prosedur yang membentuk sistem.

Pada Dira Supermarket Ambulu mulai dari tahap pemesanan/purchase order hingga prosedur pengeluaran barang dari gudang. Sistem yang diterapkan pada Dira Supermarket Ambulu baik itu sistem 
pembelian barang maupun sistem permintaan dan pengeluaran barang gudang tersebut antara lain sudah ada pemisahan fungsi yang jelas, sudah ada otorisasi atas dokumen yang digunakan dalam kegiatan pembelian, adanya surat order pembelian yang dikeluarkan oleh bagian pembelian dalam prosedur pengadaan barang, dokumen yang digunakan dalam prosedur pembelian barang persediaan sudah bernomor urut tercetak, dokumen yang digunakan sudah dibuat rangkap sehingga fungsi yang terkait dapat saling mengecek, bagian gudang mempunyai daftar persediaan barang dalam bentuk kartu gudang atau kartu stock. Namun, secara keseluruhan prosedur yang dijalankan di Dira Supermarket Ambulu belum sesuai dengan teori. Hal ini dapat dilihat dari ketidaksesuaian antara teori dan praktek yang dijalankan, diantaranya Kartu Gudang, Kartu Barang Hilang dan Rusak, Daftar Kebutuhan Barang Yang Akan Dibeli, dan Surat Pesanan Yang Dikirimkan Ke Pemasok masih perlu ditingkatkan dengan mengacu pada prinsip pemisahan fungsi operasi, fungsi penyimpanan aktiva dan fungsi pencatatan, kurangnya beberapa dokumen dan catatan akuntansi, pelaksnaan penghitungan fisik persediaan yang kurang sesuai.

Berdasarkan pada hasil penelitian yang menunjukkan kelemahan dari prosedur persediaan barang pada Dira Supermarket Ambulu, berikut beberapa saran yang diberikan untuk pengembangan lebih lanjut bagi perusahaan : Diharapkan selanjutnya mempertimbangkan untuk perbaikan terhadap perhitungan fisik persediaan/stock opname baiknya dilakukan tiga sampai empat kali dalam satu periode untuk memperkecil kesalahan-kesalahan yang mungkin terjadi pada persediaan barang, serta guna menghindari hal-hal yang dapat merugikan perusahaan, dan pada prosedur persediaan yang dijalankan sudah cukup baik, namun masih perlu ditingkatkan untuk meningkatkan kualitas perusahaan, seperti menambah beberpa dokumen dan catatan akuntansi seperti Kartu Gudang, Kartu Barang Hilang dan Rusak, Daftar Kebutuhan Barang yang akan di Beli, dan Surat Pesanan yang dikirimkan ke Pemasok, untuk meningkatkan kualitas prosedur persediaan barang.

\section{Daftar Rujukan}

Baramuli, Friska dan Pangemanan, Sifrid S. 2015. Analisis Sistem Infromasi Akuntansi Persediaan Pada Yamaha Bima Motor Toli-toli. Jurnal Akuntansi, Universitas Sam Ratulanggi Manado.

Diana, Anastasia; Setiawati, Lilis. 2017. Akuntansi Keuangan Menengah Berdasarkan Standar Akuntansi Keuangan Terbaru. Yogyakarta: CV. Andi Offset

Haidar, Iman. 2017. Analisis Sistem Informasi Akuntansi Persediaan Bahan Baku Tembakau (studi kasus pada pabrik PT. Ongkowidjojo Gadang Malang). Skripsi, Program Sarjana Universitas Islam Negeri (UIN) Maulana Malik Ibrahim Malang.

Moleong, L.J. 2012. Metodologi penelitian kualitatif. Bandung: Remaja Rosdakarya

Pah, Jendrik Piter Alexander. 2012. Pelaksanaan Sistem dan Prosedur Akuntansi Persediaan Obat-obatan pada Rumah Sakit Hewan Universitas Airlangga Surabaya. Skripsi, Program Sarjana Universitas Pembangunan Veteran Jawa Timur.

Palandeng, O.E. dan Karamoy, H. 2015. Analisis penerapan sistem informasi akuntansi persediaan barang dagangan pada PT. Hasjrat Abadi cabang Tendean. Jurnal Emba, Vol.3, No.2, 438-447.

Puspitawati, Lilis dan Anggadini, Sri Dewi. 2014. Sistem Informasi Akuntansi. Edisi pertama, Cetakan kedua, Graha Ilmu, Yogyakarta.

Rama, Gede Rainata Bayu. 2015. Analisis Penerapan Sistem Akuntansi Persediaan Material Pada PT. PLN (Persero) Distribusi Bali. Skripsi, Program Sarjana Universitas Udayana.

Santoso, Iman. 2010. Akuntansi Keuangan Menengah (Intermediate Accounting). Cetakan Kedua, Refika Aditama, Bandung.

Shofiana, Inda. 2015. Analisis Penerapan Sistem Informasi Akuntansi Persediaan Dalam Menunjang Kelancaran Proses Produksi Di Perusahaan Manufaktur Pada PT. Amitex Pekalongan Tahun 2015. Naskah Publikasi.

Sugiyono. 2009. Metode Penelitian Bisnis. Bandung: CV. Alfabeta. 
Tamodia, Widya. 2013. Evaluasi Penerapan Sistem Pengendalian Intern untuk Persediaan Barang Dagangan Pada PT. Laris Manis Utama Cabang Manado. Jurnal Akuntansi, Universitas Sam Ratulanggi Manado. 